\title{
Relationship between obesity with symptoms and findings of obstructive sleep apnea syndrome
}

\section{Obstrüktif uyku apne sendromu semptom ve bulguları ile obezite arasındaki ilişki}

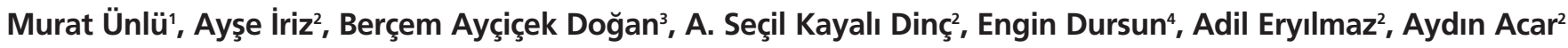 \\ ${ }^{1}$ Department of Otorbinolaryngology, Medline Hospital, Aydin, Turkey \\ ${ }^{2}$ Department of Otorbinolaryngology, Ankara Numune Training and Research Hospital, Ankara, Turkey \\ ${ }^{3}$ Division of Endocrinology and Metabolism, Department of Internal Medicine, Ankara Numune Training and Research Hospital, Ankara, Turkey \\ ${ }^{4}$ Department of Otorhinolaryngology, Recep Tayyip Erdoğan University, Rize, Turkey
}

\begin{abstract}
Objective: To evaluate the effect of obesity on obstructive sleep apnea syndrome (OSAS) by means of objective and subjective data..

Methods: A total of 70 patients were divided into obese $(\mathrm{n}=38$; BMI $\left.>35 \mathrm{~kg} / \mathrm{m}^{2}\right)$ and non-obese patient groups $\left(\mathrm{n}=32 ; \mathrm{BMI}<30 \mathrm{~kg} / \mathrm{m}^{2}\right)$. The Epworth sleepiness scale scores, modified Mallampati index scores, levels of obstruction in the oropharynx and soft palate, neck circumference and polysomnography findings between two groups were compared.

Results: Obese patients had an average Mallampati score of Class III while the non-obese study participants had an average score of Class II, with a statistically significant intergroup difference. In Muller's maneuver, the levels of obstruction in both the soft palate and oropharynx were higher in the obese patients with a statistically significant difference between two groups. When polysomnography results were examined, the average apnea-hypopnea index (AHI) score was determined to be 22.5 in the obese and 6.4 in the non-obese groups, respectively. Furthermore, average scores of rapid eye movement (REM) AHI in the non-obese and obese patients were 4.6 and 17.2 with a statistically significant difference between the groups. The average lowest oxygen saturation was $75.5 \%$ in the obese and $88 \%$ in the non-obese group, which represented a statistically significant difference between groups. In the obese group, the number of patients with REM-dependent OSAS was higher than in the nonobese group which attained a level of statistical significance.

Conclusion: Our study indicated that obesity increases the severity of OSAS, in part due to significant narrowing of the airway at the level of the soft palate and oropharynx. Additionally, our study has shown that the risk of supine position-dependent OSAS and especially REM-dependent OSAS were notably higher in obese patients.
\end{abstract}

Keywords: Obesity, obstructive sleep apnea syndrome.

\begin{abstract}
Özet
Amaç: Bu çalışmanın amacı obezitenin obstüktif uyku apne sendromu (OUAS) üzerindeki etkilerini objektif ve subjektif veriler eşliğinde degerlendirmektir.

Yöntem: Toplam 70 hasta obez ( $\mathrm{n}=38$; VKİ $35 \mathrm{~kg} / \mathrm{m}^{2}$ ) ve obez olmayan $\left(\mathrm{n}=32 ; \mathrm{VKI}<30 \mathrm{~kg} / \mathrm{m}^{2}\right)$ olmak üzere iki gruba ayrıldı. Gruplar, Epworth uykululuk skalası, modifiye Mallampati indeks skoru, orofarenks ve yumuşak damaktaki tıkanıklığın seviyesi, boyun çevresi ve polisomnografi sonuçları açısından karşılaştırıldı.
\end{abstract}

Bulgular: Obez hastalarda ortalama Mallampati skoru Sinıf III iken obez olmayan hastalarda ortalama Mallampati skoru Sınıf II idi ve gruplar arasında istatistiksel olarak anlamlı fark mevcut idi. Müller manevrasında, hem yumuşak damakta hem de orofarenksteki tıkanıklığın şiddeti obez hastalarda daha yüksek idi ve gruplar arasındaki fark istatistiksel olarak anlamlı idi. Polisomnografi sonuçları incelendiğinde, ortalama apne-hipopne indeksi (AHI) puanı obez grupta $22.5 \mathrm{iken}$ obez olmayan grupta 6.4 idi. Ayrica, obez olmayan ve obez hastalarda hızlı göz hareketi (REM) AHİ ortalama skorları 4.6 ve 17.2 idi ve gruplar arasında istatistiksel olarak anlamlı bir fark mevcuttu. Ortalama en düşük oksijen doygunluğu açısından gruplar arasında istatistiksel olarak anlamlı bir fark vardı ve doygunluk obez grupta \% 75.5 iken, obez olmayan grupta \%88 idi. Obez gruptaki REM bağımlı OUAS' hasta sayısı obez olmayan gruptan istatistiksel olarak anlamlı düzeyde daha yüksekti.

Sonuç: Bu çalışmada, obezitenin, kısmi olarak yumuşak damak ve orofarenks seviyesinde havayolunun anlamlı derecede daralmasına neden olarak, OUAS şiddetini arttırdığı ortaya konmuştur. Ek olarak, çalışmamızda, supin pozisyon bağımlı OUAS ve REM bağımlı OUAS'ın obez hasta grubunda anlamlı olarak daha yüksek düzeyde olduğu ortaya konmuştur.

Anahtar sözcükler: Obezite, obstrüktif uyku apne sendromu.
Correspondence: Ayşe Seçil Kayalı Dinç, MD. Department of Otorhinolaryngology, Ankara Numune Training and Research Hospital, 06100, Ankara, Turkey. e-mail: secilkayali81@yahoo.com

Received: December 18, 2013; Accepted: January 16, 2014; Published online: May 5, 2014
Online available at: www.jmedupdates.org doi: $10.2399 / \mathrm{jmu} .2014001003$ QR code: 
Obesity is one of the most common health problems throughout the world according to the Turkish Diabetes Epidemiology II (TURDEP II) study and it has a prevalence rate of $36 \%$ in Turkey. In addition, the worldwide obstructive sleep apnea syndrome (OSAS) rate is estimated to be between $1-5 \%$, with a slightly lower rate of 0.9 $1.4 \%$ in our country. ${ }^{[1]}$ Although risk factors for OSAS are known, the triggering mechanisms are not yet fully understood. Furthermore, many diseases such as obesity, metabolic syndrome and cardiovascular diseases have been associated with OSAS and Calle et al. discovered that the symptoms of OSAS decrease when patients lose weight and even sometimes the patients fully recover. ${ }^{[2-4]}$

Although the relationship between obesity and OSAS has been the focus of many studies, a few of them have compared OSAS in obese and non-obese population groups. In the present study, we aimed to evaluate the effect of obesity on OSAS by means of objective and subjective data.

\section{Materials and Methods Study Design}

Seventy patients with a mean age of $44.3 \pm 11.7$ (range: 24 to 72 ) years, who were seen at our polyclinic with complaints of sleep apnea and snoring were enrolled in our study. Age, gender and body mass index (BMI) of all patients were recorded. The patients also completed the Epworth sleepiness scale form, which assessed their routine sleep schedule. However, patients without any signs and/or symptoms which obviate the need for polysomnography (PSG), those under the age of 18 , individuals whose mental-conscious and orientation level were not considered to be within normal limits and those who slept inadequately during the PSG (total sleep duration $<4$ hours) were excluded from the study.

These patients were then divided into obese $(17$ males and 21 females; $\left.\mathrm{BMI}>35 \mathrm{~kg} / \mathrm{m}^{2}\right)$ and non-obese (23 males and 9 females; BMI $<30 \mathrm{~kg} / \mathrm{m}^{2}$ ) patient groups. The patients' otorhinolaryngology examination results were within normal limits and the modified Mallampati index scores, which were developed by Samsoon and Young, were determined. ${ }^{[5]}$ The severity of obstruction were determined by performing flexible endoscopic examinations and using Muller's maneuver, which determined the severity of stenosis as $1+(0-25 \%), 2+(25-50 \%), 3+(50-$ $75 \%)$ and $4+(75-100 \%)$. Later, the PSG was applied after the patients slept for an entire night and the results were simultaneously recorded.

\section{Statistical Analysis}

The analysis of data was performed utilizing the SPSS for Windows 11.5 software program (SPSS Inc., Chicago, IL, USA). Student's t-test was used to establish the statistically significant differences regarding to the averages between the two groups and the Mann-Whitney $U$ test was used to calculate the median values. Categorical variables were evaluated via Pearson's chi-square test or Fisher's exact test.

\section{Results}

Mean BMI was calculated as $38.9 \pm 4.6$ (range: 34.8 to 42.1 ) $\mathrm{kg} / \mathrm{m}^{2}$ in the obese and $22.7 \pm 2.2$ (range: 19.5 to 25.4 ) $\mathrm{kg} / \mathrm{m}^{2}$ in the non-obese groups, while mean neck circumference was $40.1 \pm 2.5$ (range: 35.0 to 45.0 ) $\mathrm{cm}$ in the obese and $38.8 \pm 1.4$ (range: 35 to 41 ) $\mathrm{cm}$ in the non-obese groups. This higher circumference in the obese patients was statistically significant $(\mathrm{p}=0.006)$. In addition, apnea-hypopnea index (AHI) and neck circumference were evaluated and a statistically significant correlation was found between these two variables $(\mathrm{p}<0.001)$. Average Epworth sleepiness scale score was 8 (range: 2 to 17) in the obese and 6 (range: 2 to 13) in the non-obese groups, respectively without any statistically significant difference between groups $(\mathrm{p}=0.106)$. Obese patients had an average Mallampati score of Class III while the non-obese study participants had an average score of Class II, with a statistically significant intergroup difference $(\mathrm{p}<0.001)$ (Fig. 1).

Muller's maneuver was performed by way of flexible endoscopic examination in our study. The level of the soft palate obstruction was also evaluated in the obese $(2+; 25-$ $50 \%)$ and non-obese $(1+; 0-25 \%)$ groups. In Muller's

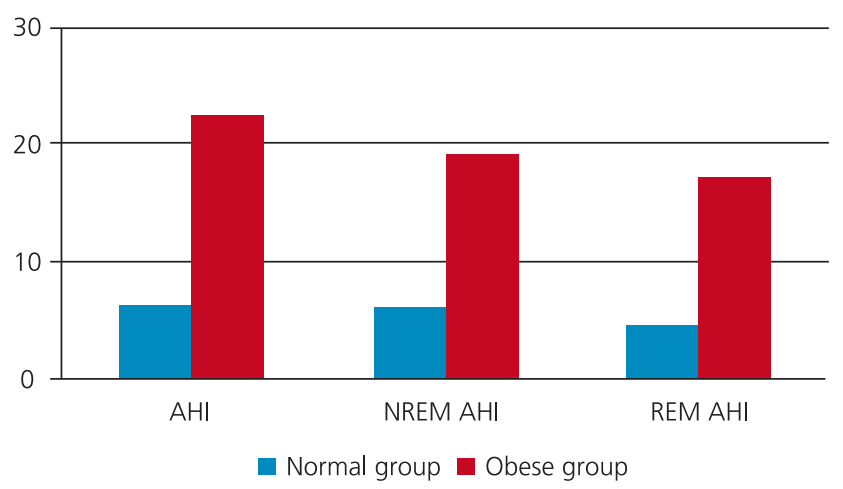

Fig. 1. Comparison of the Mallampati index scores in the obese and nonobese patient groups. 
maneuver, the levels of obstruction in both the soft palate and oropharynx were higher in the obese patients with a statistically significant difference between obese and nonobese groups ( $\mathrm{p}<0.001$ and $\mathrm{p}=0.002$, respectively) (Fig. 2).

When PSG results were examined, there was no statistically significant difference between the average percentages of obese $(84.9 \%)$ and non-obese patients (86\%) regarding sleep efficiency $(\mathrm{p}=0.597)$. The average AHI score was determined to be 22.5 (range: 2.2 to 77.2 ) in the obese and 6.4 (range: 0.1 to 19.5 ) in the non-obese groups, respectively. Furthermore, average scores of rapid eye movement (REM) AHI in the non-obese and obese patients were 4.6 (range: 0.0 to 26.8 ) and 17.2 (range: 0.0 to 85.9 ) with a statistically significant difference between the groups $(\mathrm{p}<0.001, \mathrm{p}=0.002$ and $\mathrm{p}<0.001$, respectively). The average lowest oxygen saturation was $75.5 \%$ (range: 40 to $90 \%$ ) in the obese and $88 \%$ (range: 72 to $93 \%$ ) in the non-obese group, which represented a statistically significant difference between groups $(\mathrm{p}<0.001)$. The PSG findings revealed that the frequency of simple snoring $(\mathrm{AHI}<5)$ was statistically significantly higher in the nonobese group ( $\mathrm{p}=0.003)$. However, severe OSAS (AHI>30) was seen more frequently in the obese group which was also statistically significant $(\mathrm{p}<0.001)$. Any statistical difference was not observed between the two groups in terms of the AHI scores of mild and moderate OSAS ( $>0.05)$ (Fig. 3). In the obese group, the number of patients with REM-dependent OSAS was higher than those in the nonobese group which attained a level of statistical significance $(\mathrm{p}<0.013)$. Position-dependent OSAS was more frequently seen in the non-obese group compared with the obese group, with a difference which was also deemed to be statistically significant $(\mathrm{p}=0.004)$. However, any statistical significance differences were not seen between both groups with respect to the incidence of these two types of OSAS ( $>0.05)$.

\section{Discussion}

Both OSAS and obesity are common in our society and many diseases, including obesity, metabolic syndrome and cardiovascular disease have been associated with OSAS. Furthermore, obesity is noted as being one of the seven causes of sleep disorders in the International Classification of Sleep Disorders. ${ }^{[6]}$ Obstructive sleep apnea syndrome is the most frequently seen sleep-related breathing disorder, with an observed prevalence of $2-4 \%$ in middle-aged adults and up to $20 \%$ in the elderly. ${ }^{[2,3,7]}$
Contrary to the popular belief, obesity does not necessarily correlate to being overweight precisely, but it in fact demonstrates that the fat composition in the body is redundant (higher than the average ranges detected in the non-obese population) ${ }^{[8]}$ In a Turkish study in which 24,788 individuals were scanned, obesity was detected in $30 \%$ of females, $13 \%$ of males and $22.3 \%$ of the population in general. ${ }^{[9]}$ Obesity has been found to be the major risk factor for OSAS with a $10 \%$ weight gain beyond the normal range being associated with an increased risk of developing this disorder. ${ }^{[10]}$ While obesity occurs more frequently in females, males have a markedly increased risk for OSAS, which was confirmed in our study. ${ }^{[11]}$ We have discovered that especially in the obese group, AHI scores increased more frequently in obese males than obese females and this finding was overwhelmingly statistically significant $(\mathrm{p}<0.01)$.

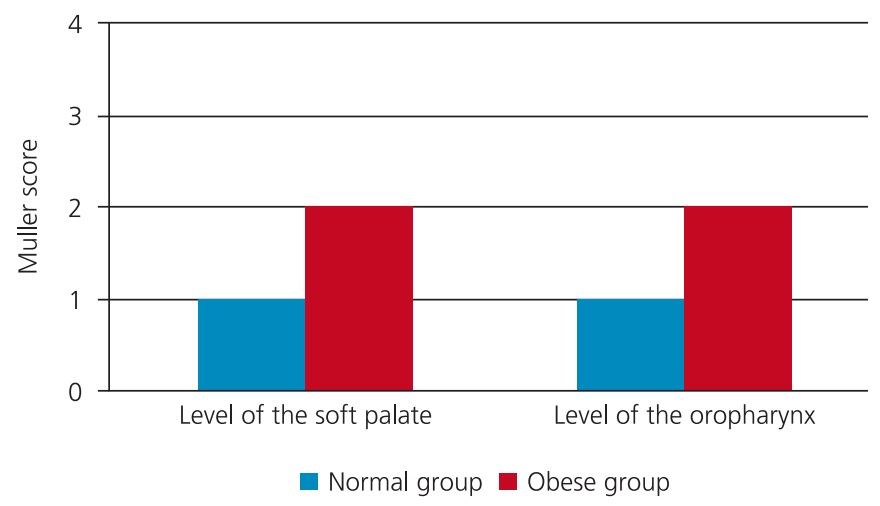

Fig. 2. Comparison of the levels of obstruction in the soft palate and oropharynx in the obese and non-obese patient groups.

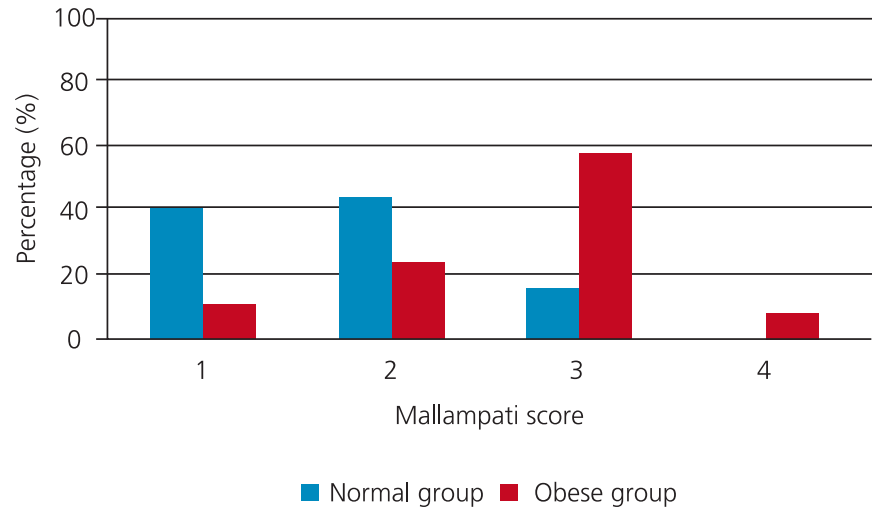

Fig. 3. Comparison of the apnea-hypopnea index (AHI) scores in the obese and non-obese patient groups. 
The mechanisms linking obesity with risk of OSAS include diminished pharyngeal lumen diameter, due to fatty tissue in the lateral walls of the airway, decreased upper airway muscle strength due to fatty deposits in the muscles and reduced upper airway diameter secondary to a mass effect of the enlarged abdomen on the chest wall and tracheal traction. ${ }^{[0-8]}$

Moreover, previous studies have demonstrated that rather than a generalized increase in fat mass, central obesity, for which abdominal obesity is used as a surrogate and fat distribution in the upper part of the body, where neck circumference is used as a marker, play key roles in the development of OSAS. ${ }^{[12]}$

The most common parameter used to evaluate the degree of obesity is BMI. The National Center for Health Statistics defines BMI between 18.5 and 24.9 as normal; BMI between 25.0 and 29.0 as overweightness and BMI greater than 30.0 as obesity. ${ }^{[10]}$ In a study published in 2001 by Resta et al., the authors determined that OSAS was observed in more than $50 \%$ of people with a BMI score of higher than $40 .^{[13]}$

Terris et al. detected a moderate relationship between collapse rates and the level of sleep apnea. ${ }^{[14]}$ In our study, we found that the levels of obstruction, detected when examining the lower levels of obstruction in both the soft palate and oropharynx via Muller's maneuver were statistically significantly correlated with the AHI scores.

A comparative study by Chiearakul et al. performed in 2007 also reported that a more significant increase in AHI scores during REM occurred in the obese patients compared to the non-obese patients. ${ }^{[15]}$ Moreover, they detected that the oxygen saturation rate was statistically significantly lower in the obese group $(\mathrm{p}<0.05)$.

Oksenberg et al. demonstrated that treatment with continuous positive airway pressure is more beneficial for obese patients lying in the supine position rather than in a lateral position and Mancini et al. determined that positional-dependent OSAS was more frequent in obese patients. ${ }^{[1,1,1]}$ In our study, we confirmed that the AHI scores increased while lying in the supine position and in the REM period, which were statistically significant findings. Furthermore, minimum oxygen saturation rate was statistically significant lower in the obese group $(\mathrm{p}<0.05)$. The total sleep duration and sleep efficiency of the patients in our two groups were similar without any statistically significant difference between groups.

\section{Conclusion}

Our study indicated that obesity increases the severity of OSAS, in part due to significant narrowing of the airway at the level of the soft palate and oropharynx. Furthermore, it should be noted that the risk is greater for males, especially when combined with obesity. Additionally, our study has shown that the risk of supine position-dependent OSAS and especially REM-dependent OSAS were notably higher in obese patients.

Conflict of Interest: No conflicts declared.

\section{References}

1. Köktürk O. Obstrüktif uyku apne sendromu epidemiyolojisi. Tüberküloz ve Toraks Dergisi 1998;46:193-201.

2. Liu PY, Caterson ID, Grunstein RR, Handelsman DJ. Androgens, obesity and sleep-disordered breathing in men. Endocrinol Metab Clin North Am 2007;36:349-63.

3. Collop NA, Adkins D, Phillips BA. Gender differences in sleep and sleep-disordered breathing. Clin Chest Med 2004;25:25768.

4. Calle EE, Thun MJ, Petrelli JM, Rodriguez C, Heath CW Jr. Body-mass index and mortality in a prospective cohort of U.S. adults. N Engl J Med 1999;341:1097-105.

5. Samsoon GLT, Young JRB. Difficult tracheal intubation: a retrospective study. Aneasthesia 1987;42:487-90.

6. Mokhlesi B. Obesity hypoventilation syndrome: a state of the art review. Respir Care 2010;5 5:1347-62.

7. Ancoli-Israel S, Kripke DF, Klauber MR, Mason WJ, Fell R, Kaplan O. Sleep disordered breathing in community-dwelling elderly. Sleep 1991;14:486-95.

8. Jebb SA. Vücut bileşiminin ölçülmesi: laboratuardan kliniğe. In: Kopelman PG, Stock MJ, editors. Klinik obezite. 1. Bask1. İstanbul: AND Yayınc1lı; 2000. p.18-49.

9. Stevens J, Cai J, Pamuk ER, Williamson DF, Thun MJ, Wood $\mathrm{JL}$. The effect of age on the association between body-mass index and mortality. N Engl J Med 1998;338:1-7.

10. Newman AB, Nieto FJ, Guidry U, et al.; Sleep Heart Health Study Research Group. Relation of sleep-disordered breathing to cardiovascular disease risk factors: the Sleep Heart Health Study. Am J Epidemiol 2001;154:50-9.

11. Oranzo JA, Scott JG. Diagnosis and treatment of obesity in adults: an applied evidence-based review. J Am Board Fam Pract 2004;17:359-69.

12. Degache F, Sforza E, Dauphinot V, et al. Relation of central fat mass to obstructive sleep apnea in the elderly. Sleep 2013;36:501-7.

13. Resta O, Foschino-Barbaro MP, Legari G, et al. Sleep related breathing disorders, loud snoring and excessive daytime sleepiness in obese subjects. Int J Obes Relat Metab Disord 2001;25: $669-75$. 
14. Terris DJ, Hanasono MM, Liu YC. Reliability of the Muller maneuver and its association with sleep-disordered breathing. Laryngoscope 2000;110:1819-23.

15. Chierakul N1, Chaipattarapol C, Ruttanaumpawan P, Nana A, Naruman C, Tangchityongsiva S. Comparison of clinical and polysomnographiccharacteristicsof non-obese and obese patients with obstructive sleep apnea. J Med Assoc Thai 2007;90:48-53.
16. Oksenberg A, Silverberg DS, Arons E, Radwan H. The sleep supine position has a major effect on optimal nasal continuous positive airway pressure : relationship with rapid eye movements and non-rapid eye movements sleep, body mass index, respiratory disturbance index, and age. Chest 1999;116:1000-6.

17. Mancini M, Aloe F, Tavares S. Sleep apnea in obese. [Article in Portuguese] Arquivos Brasileiros de Endocrinologia \& Metabologia 2000;44:81-90.

This is an open access article distributed under the terms of the Creative Commons Attribution-NonCommercial-NoDerivs 3.0 Unported (CC BYNC-ND3.0) Licence (http://creativecommons.org/licenses/by-nc-nd/3.0/) which permits unrestricted noncommercial use, distribution, and reproduction in any medium, provided the original work is properly cited.

Please cite this article as: Ünlü M, İriz A, Doğan BA, Kayalı Dinç AS, Dursun E, Eryılmaz A, Acar A. Relationship between obesity with symptoms and findings of obstructive sleep apnea syndrome. J Med Updates 2014;4(1):11-15. 